\title{
Kekuatan Putusan Komisi Pengawas Persaingan Usaha (KPPU) dalam Penegakan Hukum Persaingan Usaha
}

\author{
I Made Indra Praja W. \\ Program Studi Magister Ilmu Hukum Universitas Mataram \\ Email: imadeindra@gmail.com
}

\begin{abstract}
ABSTRAK
Kedudukan atau status dari KPPU dalam menjalankan fungsi kewenangannya menjadi hal yang sangat penting, mengingat Undang-Undang nomor 5 Tahun 1999 telah memberikan KPPU kewenangan yang sangat besar, sehingga menyerupai kewenangan lembaga peradilan (quasai judicial). Pasal 35 dan Pasal 36 Undang-Undang No. 5 Tahun 1999 secara tegas memberikan kewenangan yang sangat luas kepada KPPU untuk dapat berlaku sebagai penyidik, penuntut maupun sebagai pemutus terhadap kasus-kasus persaingan usaha. dalam konteks demikian maka timbul opini yang menganggap bahwa KPPU adalah sebagai peradilan khusus untuk kasus persaingan usaha. Dipandang dari sifat putusan KPPU yang otomatis memiliki kekuatan hukum tetap apabila terhadapnya tidak diajukan keberatan dan penegakan melalui mekanisme penetapan untuk eksekusi ke pengadilan negeri, maka proses hukum yang seharusnya melanjuti proses penegakan putusan KPPU adalah upaya hukum eksekusi, yang didasarkan kepada penetapan eksekusi pengadilan negeri. Putusan KPPU tidak bisa eksekusi oleh KPPU sendiri, karena dalam kepala putusan tidak mencantumkan irah-irah "Demi Keadilan Berdasarkan Ketuhan yang Maha Esa".
\end{abstract}

Kata Kunci: Kekuatan Putusan KPPU, Penegakan Hukum, Persaingan Usaha

\begin{abstract}
The position or status of KPPU in carrying out its functions of authority becomes very important, considering that Law Number 5 Year 1999 has given KPPU an enormous authority, thus resembling the authority of the judicial institution (quasai judicial). Article 35 and Article 36 of Law no. 5 of 1999 expressly gives wide authority to KPPU to be able to act as investigator, prosecutor or as a breaker in cases of business competition. in such context, an opinion arises that KPPU is a special court for the case of business competition. Judging from the nature of KPPU's decision which automatically has permanent legal force if against it is not filed an objection and enforcement through the mechanism of determination for execution to the district court, the legal process which should continue the enforcement process of KPPU decision is the execution law, based on the determination of the execution of the district court. KPPU's decision can not be executed by KPPU itself, because in the head of the decision does not mention the "Justice for Justice's Divine Justice".
\end{abstract}

Key Words: The Power of KPPU's Decisions, Law Enforcement, Business Competition 


\section{A. PENDAHULUAN}

Sehubungan dengan larangan praktek monopoli dan persaingan usaha tidak sehat dalam perdagangan telah terbukti merugikan rakyat. Dalam hal ini Posner berpendapat ada tiga alasan praktisi mengapa praktek monopoli tidak dikehendaki yaitu ${ }^{1}$ :

Pertama, bahwa monopoli mengalihkan kekayaan dari para konsumen kepada para pemegang saham perusahaan monopolistik yaitu suatu distribusi ke-kayaan yang berlansung dari golongan yang kurang mampu kepada yang kaya.

Kedua, monopoli, atau secara lebih luas setiap kondisi yang menjadi kuat kerja-sama diantara perusahaanperusahaan yang bersaing akan mempermudah dunia industri untuk melakukan monopolasi politik, guna dapat memperoleh proteksi dalam bentuk peraturan perundang-undangan yang memungkinkan perolehan keuntungan di bidang industri yang bersangkutan.

Ketiga, adalah berkiatan dengan keberata monopoli yakni bahwa kebijakan anti monopoli yang bertujuan untuk mengakibatkan efisiensi, merupakan kebijakan yang membatasi kebebasan bertindak bagi perusahaan-perusahaan besar untuk dapat berkembangnya perusahaan-perusahaan kecil.

Dalam perkembangan hukum persaingan, ternyata penyelesaian sengketa persaingan usaha tidak semata-mata merupakan sengketa perdata. Pelanggaran terhadap hukum persaingan mempunyai unsur-unsur pidana bahkan administrasi. Hal ini disebabkan pelanggaran terhadap hukum persaingan pada akhimya akan merugikan masyarakat dan merugikan per-

${ }^{1}$ Richard A Posner, Anti Trust Law (an Economic Persfetive) dalam A. M. Tri Anggraeni, Larangan Praktek Monopoli dan Persaingan Usaha Tidak Sehat Perse Ilegal atau Rule of Regoin, Fak. Hukum Universitas Indonesia, Jakarta, 2003, hlm. 6-7 ekonomian negara. Oleh karenanya, di samping penyelesaian sengketa secara perdata, penyelesaian sengketa persaingan usaha dilakukan juga secara pidana. ${ }^{2}$

Adapun institusi yang diberi kewenangan oleh negara untuk penanganan perkara pelanggaran hukum persaingan usaha diatur secara berbeda dengan tindak pidana pada umumnya. Institusi ini dibentuk dan diberi kewenangan berdasarkan peraturan perundang-undangan. Di Indonesia berdasarkan UU No. 5 Tahun 1999 institusi yang memiliki kewenangan untuk sengketa persaingan usaha adalah Komisi Pengawas Persaingan Usaha (KPPU). ${ }^{3}$

Pemberian kewenangan khusus kepada suatu komisi untuk melaksanakan suatu peraturan di bidang persaingan adalah hal yang dilakukan oleh kebanyakan negara. Misalnya, di Amerika Serikat dengan Federal Trade Commission, ${ }^{4}$ Ma-syarakat Ekonomi Eropa $^{5}$ dengan European Community Commission. Jepang, Korea, dan Taiwan dengan Fair Trade Commission-nya. Praktik di be-berapa negara ada yang mengatur ke-beradaan komisi khusus ini dengan undang-undang tersendiri, ada juga yang meng-gabungkan pengaturannya dalam undang-undang persaingan usahanya. Amerika Serikat adalah contoh negara yang me-ngatur keberadaan komisi, khusus dalam undang-undang tersendiri. Adapun contoh negara yang menyatukan pengaturan ke-beradaan Komisi tersebut dalam undang-undang persaingan usahanya adalah Jepang, demikian juga dengan Indonesia ${ }^{6}$.

2 Susanti Adi Nurgroho, Hukum Persaingan Usaha di Indonesia Dalam Teori dan Praktik Serta Penerapan Hukumnya, Kencana, Jakarta, 2014, hlm. 539

${ }^{3}$ Ibid, hlm. 540

${ }^{4}$ Ibid

5 Ralph H. Folsoni dan Michael W. Gordon, Internasional Business Transactions, (St. Paul: Westt Publishing Co.1995), hlm. 876

${ }^{6}$ Susanti Adi Nugroho, Op. Cit, hlm. 542 
Pengaturan tentang penanganan perkara pelanggaran hukum persaingan usaha juga tersebar di dalam beberapa peraturan, yakni:

1. UU No. 5 Tahun 1999 tentang Larangan Praktik Monopoli dan Persaingan Usaha Tidak Sehat;

2. Keputusan Presiden No. 75 tahun 1999 tentang Komisi Pengawas Persaingan Usaha atau KPPU, sebagaimana telah diubah dengan Peraturan Presiden No. 80 Tahun 2008;

3. Peraturan Komisi No. 2 Tahun 2008 tentang Kewenangan Sekretariat Komisi dalam Penganan Perkara;

4. Peraturan Komisi (PERKOM) No. 1 Tahun 2006 yang kemudian diperbarui dengan PERKOM No. 1 Tahun 2010, tentang Tata Cara Penanganan Perkara di KPPU;

5. Peraturan Mahkamah Agung No. 1 Tahun 2003 mengenai Tata Cara Pengajuan Upaya Hukum Keberatan Terhadap Putusan KPPU yang telah diperbarui dengan Peraturan Mahkamah Agung No. 3 Tahun 2005;

6. HIR/RBg atau hukum acara perdata, yaitu untuk ketentuan hukum acara perdata jika pelaku usaha menyatakan keberatan atas putusan KPPU sesuai dengan Pasal 44 ayat (2) UU No. 5 Tahun 1999, atau apabila terdapat gugatan perdata yang didasarkan pada adanya putusan KPPU yang telah berkekuatan hukum tetap (follow-on claims);

7. KUHAP, yaitu ketentuan hukum acara pidana jika perkara tersebut dilimpahkan ke pihak penyidik sesuai Pasal 44 ayat (4) UU No. 5 v Tahun 1999.

Apabila kita melihat Pasal 44 dan Pasal 45 Undang-Undang No. 5 Tahun 1999, pasal-pasal tersebut banyak berbicara dalam kaitannya dengan peradilan. Masalah yang dihadapi adalah
UU No. 5 Tahun 1999 memberikan kewenangan yang besar ke-pada KPPU, di mana dalam undang-undang tersebut terdapat aspek pidana dan aspek administrasi, sehingga dalam pelaksanaannya pun harus ditetapkan suatu batasan apakah KPPU merupakan suatu badan peradilan dalam arti kekuasaan kehakiman yang dimaksud Pasal 24 dan seterusnya dari Undang-Undang No. 4 Tahun 2004 tentang Kekuasaan Kehakiman.

Komisi Pengawas Persaingan Usaha (KPPU) adalah lembaga publik, penegak dan pengawas pelaksanaan UU No. 5 Tahun 1999, serta wasit independen dalam rangka menyelesaikan perkara-perkara yang ber-kaitan dengan larangan monopoli dan per-saingan usaha tidak sehat. Terkait dengan itu, maka tugas dan wewenang dari KPPU sebagaimana ditentukan dengan jelas dan tegas baik dalam UU No. 5 Tahun 1999. maupun dalam Keputusan Presiden Republik Indonesia No. 75 Tahun 1999 adalah instrumen hukum yang mempunyai peranan penting dalam rangka mewujudkan sistem ekonomi pasar yang mendorong efisiensi produksi, konsumsi, dan alokasi.

Kedudukan atau status dari KPPU dalam menjalankan fungsi kewenangannya menjadi hal yang sangat penting untuk didiskusikan, mengingat UU No. 5 Tahun 1999 telah memberikan KPPU kewenangan yang sangat besar menyerupai kewenangan lembaga peradilan (quasi idicial). Kewenangan komisi yang menyerupai lembaga yudikatif adalah kewenangan komisi melakukan fungsi penyelidikan, memeriksa, memutus, dan akhirnya men-jatuhkan hukuman administratif atas per-kara diputusnya. Demikian juga ke-wenangannya menjatuhkan sanksi ganti rugi atau denda kepada pelaku usaha terlapor.

Sebagai lembaga yang diberi wewenang oleh UU untuk mengawasi dan melakukan penegakan di bidang persaingan usaha, KPPU berhak 
memberikan putusan kepada pelaku usaha atau kegiatan usaha yang dinilai dapat merugikan pelaku usaha, masyarakat dan kepentingan umum. Namun pada kenyataannya, sanksi yang diputuskan oleh KPPU dan dijatuhkan kepada pelaku usaha yang dinyatakan melanggar UndangUndang Nomor 5 Tahun 1999, tidak dapat dilaksanakan sepenuhnya.

Dalam UU ini disebutkan bahwa KPPU sebagai lembaga yang berwenang memutus perkara terkait dengan monopoli dan persaingan usaha tidak sehat dengan memberikan sanksi administratif atau putusan kepada pelaku usaha yang dinilai dapat merugikan masyarakat dan pelaku usaha lainnya. Putusan yang dikeluarkan oleh KPPU ini didasarkan pada ketentuan yang telah tercantum dalam UndangUndang No. 5 Tahun 1999. Berdasarkan Pasal 43 ayat (3) UU ini dijelaskan bahwa KPPU berwenang untuk memutuskan telah terjadi atau tidak terjadi pelanggaran terhadap UU ini dengan didahului dengan sebuah acara pemeriksaan. Artinya, KPPU berhak memutus sebuah bentuk usaha dan perilaku usaha apakah melanggar hukum persaingan usaha atau tidak.

Putusan yang sudah ditetapkan oleh KPPU berdasarkan Pasal 43 UU Nomor 5 Tahun 1999, putusan tersebut telah memiliki kekuatan hukum yang tetap, apabila tidak ada keberatan dari pihak pelaku usaha yang dianggap bersalah. Ini berarti bahwa keputusan KPPU bukan merupakan ke-putusan yang bersifat final, karena masih dimungkinkan adanya upaya hukum untuk mengajukan kembali putusan tersebut me-lalui upaya hukum keberatan ke Pengadilan Negeri.

Dari uraian diatas permasalahan yang akan dibahas melalui tulisan ini yaitu Bagaimanakah kekuatan putusan KPPU dalam penegakan hukum persaingan usaha. Jenis penelitian yang dilakukan dalam penelitian ini adalah penelitian yuridis normatif dengan melakukan pendekatan pengkajian terhadap peraturan perundangundangan yang menjadi tema sentral dari tema penelitian seperti Undang-Undang No. 5 Tahun 1999, Peraturan Presiden No. 80 Tahun 2008. Pendekatan Konsep (Conseptual Approach) dan Pendekatan Analitis (Analitical Approach). Analisis yang digunakan dalam penelitian ini dilakukan adalah analisis preskriptif yaitu sifat analisis ini dimaksudkan untuk memberikan argumentasi atas hasil penelitian yang telah dilakukan. Argumentasi di sini dilakukan oleh peneliti untuk memberikan preskripsi atau penilaian mengenai benar atau salah apa yang seyogyanya menurut hukum terhadap fakta atau peristiwa hukum dari hasil penelitian.

\section{B. PEMBAHASAN}

\section{Penegakan Keputusan Komisi Penga-was Persaingan Usaha}

\section{a. Tata Cara Penanganan Perkara Pene-gakan Hukum Persaingan Usaha}

Undang-Undang Nomor 5 Tahun 1999 lebih lanjut mengatur tata cara penanganan perkara penegakan hukum persaingan usaha pada Pasal 38 sarnpai dengan Pasal 46. Dalam menangani perkara pe-negakan hukum persaingan usaha, Komisi Pengawasan Persaingan usaha dapat me-lakukannya secara proaktif atau dapat menerima pengaduan atau laporan dari masyarakat. Pasal 40 UndangUndang Nomor 5 Tahun 1999 menyatakan bahwa Komisi Pengawas Persaingan Usaha dapat melakukan pemeriksaan terhadap pelaku usaha apabila ada dugaan terjadi pe-langgaran Undang-Undang Nomon 5 Tahun 1999 ini walaupun tidak ada laporan yang memeriksaannya dilaksanakan sesuai tata cara sebagaimana diatur dalam Pasal 39. Sebelumnya, dalam Pasal 38 Undang-Undang Nomor 5 Tahun 1999 dinyatakan bahwa setiap orang yang mengetahui bahwa telah tenjadi atau patut diduga telah terjadi pelanggaran terhadap Undang-Undang Nomor 5 Tahun 1999 ini dapat me-laponkannya secara tertulis kepada Komisi Pengawas Persaingan Usaha dengan ke-terangan yang jelas 
tentang telah terjadinya pelanggaran, dengan menyertakan identitas pelapor. Demikian pula pihak yang di-rugikan sebagai akibat terjadinya pe-langgaran terhadap Undang-Undang Nomor 5 Tahun 1999 ini dapat melaporkan secara tertulis kepada Komisi Pengawas Persaingan Usaha dengan keterangan yang lengkap dan jelas tentang telah terjadinya pelanggaran serta kerugian yang ditimbulkan, dengan menyertakan identitas pelapor. Dengan demikian dapat disimpulkan bahwa bahan penyelidikan, pemeriksaan, dan/atau penelitian terhadap kasus dugaan praktik monopoli dan atau persaingan usaha tidak sehat bisa berasal dari laporan atau pengaduan pihak-pihak yang dirugikan atau pelaku usaha; bahkan dari masyarakat atau setiap orang yang mengetahui bahwa telah terjadi atau patut diduga telah terjadi pelanggaran UndangUndang Nomor 5 Tahun 1999. Hal ini bisa disampaikan kepada Komisi Pengawas Persaingan Usaha.

Sebagai jaminan atas diri pelapor, Pasal 38 ayat (2) Undang-Undang Nomor 5 Tahun 1999 mewajibkan Komisi Pengawas Persaingan Usaha untuk merahasiakan identitas pelapon, terutama pelapor yang bukan pelaku usaha yang dirugikan ${ }^{7}$.

\section{b. Pemeriksaan Pendahuluan dan Lan- jutan}

Pasal 39 Undang-Undang Nomor 5 Tahun 1999 mewajibkan Komisi Pengawas Pensaingan Usaha untuk melakukan pemeriksaan pendahuluan berdasankan laporan masyarakat, pihak yang dirugikan, atau pelaku usaha. Berdasarkan pemeriksaan pendahuluan ini, Komisi Pengawas Persaingan Usaha dalam waktu (selambat-lambatnya) 30 (tiga puluh) hari setelah menerima laporan tersebut, akan menetapkan perlu tidaknya dilakukan pemeriksaan lanjutan.

Menurut Pasal 41 Undang-Undang Nomor 5 Tahun 1999, selama penyelidikan atau pemeriksaan lanjutan berlangsung, pelaku usaha dan/atau pihak lain yang diperiksa mempunyai kewajiban menyerahkan alat bukti yang diperlukan dan dilarang menolak untuk diperiksa, dilarang menolak memberikan informasi yang diperlukan, dan dilarang menghambat proses penyelidikan dan/atau pemeriksaan yang dilakukan Komisi Pengawas Persaingan Usaha. Oleh kanena itu, bila pelaku usaha menolak diperiksa atau memberi informasi yang diperlukan oleh Komisi ia akan diserahkan kepada penyidik untuk disidik sesuai ketentuan yang berlaku.

\section{c. Jangka Waktu pemeriksaari Lanjutan}

Pasal 43 Undang-Undang Nomor 5 Tahun 1999 menguraikan tentang jangka waktu pemeriksaan lanjutan oleh Komisi Pengawas persaingan Usaha. Pemeniksaan lanjutan yang dilakukan Komisi Pengawas Persaingan Usaha tersebut wajib diselesaikan dalam jangka waktu selambatlambatnya 60 (enam puluh) hari sejak dilakukan pemeriksaan lanjutan. Selama jangka waktu tersebut, Komisi ngawas Persaingan Usaha telah selesai melakukan pemeriksaan dan penilaian tenhadap alat-alat bukti, yang bisa berupa keterangan saksi, keterangan dari surat dan/atau dokumen, petunjuk, dan rngan pelaku usaha. Namun jika diperlukan atau jika Komisi Pengawas Persaingan Usaha belum selesai melakukan pemeriksaan alat-alat bukti jangka waktu pemeriksaan lanjutan tersebut dapat di-perpanjang, paling lama 30 (tiga puluh) hari. Dalam kurun waktu tersebut pe-meriksaan lanjutan harus diselesaikan. Setelah selesai melakukan pemeniksaan lanjutan baik dengan atau tanpa per-panjangan jangka waktu pemeriksaan selambat-lambatnya 30 (tiga puluh) hari ter-hitung sejak pemeiiksaan lanjutan tersebut selesai, Komisi Pengawas Persaingan Usaha wajib memutuskan apakah telah terjadi atau tidak terjadi pelanggaran terhadap hukum persaingan usaha.

${ }^{7}$ Lanny Kusumawati, Op. Cit, hlm. 164. 


\section{d. Putusan Komisi}

Undang-Undang Nomor 5 Tahun 1999 tidak mengatur secara rinci bagaimana proses pengambilan putusan Komisi Pe-ngawas Persaingan Usaha. Hanya saja dalam penjelasan Pasal 43 ayat (3) Undang-Undang Nomor 5 Tahun 1999 dinyatakan bahwa pengambilan keputusan Komisi di-lakulcan dalarn suatu sidang Majelis yang beranggotakan sekurangkurangny 3 (tiga) orang anggota Komisi. Senada dengan ini, Pasal 7 Keputusan Presiden Nomor 75 Tahun 1999 menyatakan bahwa untuk me-nyelesaikan suatu perkara, Komisi Pe-ngawas Persaingan Usaha bisa melakukan sidang majelis, yang beranggotakan sekurangkurangnya 3 (tiga) orang anggota Komisi Pengawas Persaingan Usaha, di mana keputusannya ditandatangani oleh seluruh anggota majelis. Dengan demikian penyelesaian atau pemeriksaan perkara penegakan hukum persaingan harus dilakukan dalam sidang yang berbentuk majelis, majelisnya beranggotakan minimal 3 (tiga) orang.

Konsep pengaturan seperti di atas sangat dipengaruhi oleh pengaturan pengambilan keputusan sidang majelis pada peradilan umum, di mana suatu putusan dikatakan sebagai putusan majelis hakim, walaupun mungkin ada anggota majelis yang tidak setïju terhadap putusan tersebut. Seyogyanya berkas putusan tersebut harus memuat seluruh pendapat anggota majelis hakim, yang mana yang setuju, yang mana yang tidak setuju beserta alasannya, sehingga masyarakat dapat menilai kredibilitas dan hakim yang rnemeriksa per-kara tersebut. Oleh karena itu, proses pe-ngambilan putusan dalam Komisi Pe-ngawas Persaingan Usaha sebaiknya di-lakukan dengan suara terbanyak, sehingga diketahui anggota mana yang setuju, mana yang tidak setuju, serta apa alasannya. Pendapat dan masingmasing anggota yang tidak setuju tersebut harus juga dimasukkan ke dalam dokumen putusan Komisi Pe-ngawas Persaingan
Usaha. Dengan demikian kredibilitas dan masing-masing anggota dapat diketahui dan setiap putusan yang dijatuhkan Komisi Pengawas Per-saingan Usaha ${ }^{8}$.

Dalam hal ini, sudah sewajannyalah Komisi Pengawas Persaingan Usaha diberi kewenangan untuk mempertahankan putusannya dengan mengajukannya ke pengadilan jika putusan tersebut sangat berkaitan erat dengan kepentingan publik (public interest). Biarkanlah pengadilan yang menguji putusan Komisi Pengawas Persaingan Usaha tersebut ${ }^{9}$.

Dengan diterimanya putusan Komisi Pengawas Pensaingan Usaha oleh pelaku usaha, dengan sendirinya pelaku usaha wjib melaksanakan putusan yang diterimanya putusan dari Komisi Pengawas Persaingan Usaha dan melaporkan pelaksanaannya kepada Komisi Pngawas Persaingan Usaha dalam tenggang waktu 30 (tiga puluh) hari sejak menerima pemberitahuan petikan putusan Komisi Pengawas Persaingan Usaha.

\section{e. Sanksi yang Dapat di Jatuhkan oleh KPPU}

Seperti yang ditentukan dalam Pasal 36 huruf (1), KPPU mempunyai wewenang untuk menjatuhkan sanksi berupa tindakan administratif kepada pelaku usaha yang melanggar ketentuan undang-undang ini. Sanksi tindakan administratif yang dapat dijatuhkan oleh KPPU sebagaimana ditentukan dalam Pasal 36 huruf (1) di atas, diperinci kembali dalam Pasal 47 UU No. 5 Tahun 1999. Namun demikian, di dalam ke-tentuan Pasal 47 UU No. 5 Tahun 1999 hanya disebutkan bahwa:

a. Komisi berwenang menjatuhkan sanksi berupa tindakan administratif terhadap pelaku usaha yang melanggar ketentuan undang-undang ini.

b. Tindakan administratif sebagaimana dimaksud ayat (1) dapat berupa....

\footnotetext{
${ }^{8}$ Ayudha D. Prayoga, Ibid, hlm. 136-137.

${ }^{9}$ Lanny Kusumawati.,Op. Cit, hlm. 167.
} 
Unsur "tindakan administratif dapat berupa ..." dalam pasal ini, tidak memberikan batasan atas tindakan administratif yang mana dapat dijatuhkan oleh KPPU. Ada beberapa contoh kasus yang menunjukkan bahwa KPPU menjatuhkan sanksi tindakan administratif, tetapi tidak disebutkan ketentuan dalam Pasal 47 ayat (2) UU No. 5 tahun 2009 yang mana yang dilanggar, di antaranya ${ }^{10}$ : Perkara Tender Penjualan Saham PT Indomobil Sukses International dalam Putusan KPPU No. 03/KPPU-I/2002, di mana dalam amar putusan butir ke-4 KPPU melarang PT Trimegah Securities (Terlapor II), PT Cipta Sarana Duta Perkasa (Terlapor III), dan PT Deloitte \& Touche FAS (Terlapor $\mathrm{X})$ untuk mengikuti transaksi baru dalam bentuk apa pun di lingkungan dan/atau dengan Badan Penyehatan Perbankan Nasional (BPPN) dan/atau dengan pihak lain yang ditunjuk oleh atau atas kuasa BPPN berkaitan dengan pelaksanaan tugas-tugas BPPN, baik dalam penyehatan perbankan, pe-nyelesaian aset bank, maupun dalam pe-ngembalian uang negara, dalam jangka waktu dua tahun terhitung sejak tanggal dibacakannya putusan, dengan denda atas pelanggaran sebesar 30\% dan nilai setiap transaksi.

Dari contoh tersebut, perlu untuk ditegaskan mengenai sanksi administratif apa saja yang dapat dijatuhkan oleh KPPU. Hal ini dipeerlukan untuk menghindari terjadinya pelanggaran batas an oleh KPPU.

Dari Pasal 47 sampai dengan Pasal 49 UU No. 5 Tahun 1999, terdapat tiga macam sanksi yang dapat dijatuhkan kepada pelaku usaha yang melanggar hukum persaingan usaha. Ketiga macam sanksi tersebut me-liputi tindakan administratif yang di-jatuhkan KPPU, sanksi pidana pokok, dan sanksi pidana tambahan yang dijatuhkan pengadilan.

Pasal 47 UU No. 5 Tahun 1999 menyatakan, bahwa KPPU berwenang untuk menjatuhkan sanksi berupa tindakan ad- ministratif terhadap pelaku usaha yang melanggar ketentuan UU No. 5 Tahun 1999. Tindakan administratif tersebut dapat berupa: ${ }^{11}$

\section{f. Penetapan Pembatalan Perjanjian}

Sebagaimana dimaksud dalam: perjanjian-perjanjian oligopoli (Pasal 4), penetapan harga (Pasal 5), diskriminasi harga (Pasal 6), pengekangan harga diskon (Pasal 7), pengekangan harga distributor (Pasal 8), pembagian wilayah (Pasal 9), pemboikotan Pasal 10), kartel (Pasal 11), trust (Pasal 12), oligopsoni (Pasal 13), perjanjian tertutup (Pasal 15), dan perjanjian dengan pihak luar negeri (Pasal 16).

\section{g. Perintah kepada pelaku usaha untuk menghentikan integrasi vertikal (Pasal 14)}

Perintah menghentikan integrasi vertikal yang dapat mengakibatkan persaingan usaha tidak sehat dan/atau merugikan masyarakat dilaksanakan dengan perintah untuk:

1) membatalkan perjanjian tersebut; atau

2) mengalihkan sebagian perusahaan kepada pelaku usaha lain; atau

3) perubahan bentuk rangkaian produksi.

Dalam persektif persaingan, integrasi vertikal pada dasarnya tidak dilarang karena dapat rnenghasilkan efisiensi ekonomi dan mengurangi biaya transaksi. Namun de-mikian, integrasi vertikal juga dapat di-salahgunakan sehingga menimbulkan per-saingan usaha tidak sehat dan/atau me-rugikan masyarakat.

\section{h. Perintah kepada pelaku usaha untuk menghentikan kegiatan yang terbukti menimbulkan praktik monopoli dan/atau menyebabkan persaingan usaha tidak sehat dan/atau merugikan masyarakat.}

Diperintahkan untuk dihentikan di sini hanya suatu kegiatan atau tindakan 
tertentu, dan bukan kegiatan usaha pelaku usaha secara keseluruhan; pengertian dari Pasal 47 ayat (2) huruf c di atas adalah, Kornisi berwenang menjatuhkan tindakan administratif berupa perintah penghentian kegiatan yang menimbulkan:

\section{1) Praktik Monopoli}

Kegiatan yang menimbulkan praktik monopoli tercantum dalam Pasal 4 ayat (1), Pasal 9, Pasal 11, Pasal 12, Pasal 13 ayat (1), Pasal 16, Pasal 17 ayat (1), Pasal 18 ayat (1), Pasal 19, Pasal 20, Pasal 26 huruf C, Kerta Pasal 28 ayat (1) dan (2).

\section{2) Persaingan Usaha Tidak Sehat}

Kegiatan yang menimbulkan persaingan usaha tidak sehat tercanturn dalam Pasal 4 ayat (1), Pasal 7, Pasal 8, Pasal 9, Pasal 11, Pasal 12, Pasal 13 ayat (1), Pasal 14, Pasal 16, Pasal 17 ayat (1), Pasal 18 ayat (1), Pasal 19, Pasal 20, Pasal 21, Pasal 22, Pasal 23, Pasal 26 huruf c, serta Pasal 28 ayat (1) dan (2).

3) Merugikan Masyarakat

Kegiatan yang merugikan masyarakat sebagaimana tercantum dalam Pasal 14.

\section{i. Perintah kepada pelaku usaha untuk menghentikafl penyalahgunaan posisi dominan}

Posisi dominan pada dasarnya tidak dilarang oleh UU No. 5 tahun 1999, karena masyarakat mendapatkan rnanfaat dari skala ekonorni perusahaan melalui kehadiran produk yang lebih murah, kualitas lebih baik, dan variasi produksi. Pengertian penyalahgunaan posisi dominan yang dilarang dalam UU No. 5 tahun 1999 ialah sebagaimana ditentukan dalam Bab 5 UU No. 5 Tahun 1999 mengenai posisi dominan yang mencakup Pasal 25, 26, 27, 28 dan 29.

\section{j. Penetapan pembatalan atas peng- gabungan atau peleburan badan}

usaha dan pengambilalihan saham (Pasal 28)

Penggabungan peleburan dan/atau pe-ngambilalihan badan usaha pada dasarnya tidak dilarang karena dapat menimbulkan manfaat efisiensi bagi masyarakat. Namun demikian, jika suatu penggabungan, pe-leburan, dan pengambilalihan badan usaha (persero) terbukti dapat mengakibatkan ter-jadinya praktik monopoli dan/atau praktik persaingan usaha tidak sehat, maka KPPU berwenang untuk membatalkan penggabungan, peleburan clan pengambilalihan badan usaha. Pembatalan yang dimaksudkan adalah pembatalan dem hukum sehingga badan usaha yang dikenakan putusan tersebut wajib untuk kembali pada kondisi awal sebelum terjadinya penggabungan, peleburan dan pengambilalihan.

\section{k. Penetapan pembayaran ganti rugi}

Ganti rugi diberikan kepada pelaku usaha dan/atau kepada pihak lain yang dirugikan. Dalam Pedoman Keputusan KPPU No. 252/ KPPU/Kep/VII/2008 ganti rugi didefinisikan sebagai: "Ganti rugi merupakan kompensasi yang harus dibayarkan oleh pelanggar terhadap kerugian yang timbul akibat tindakan antipersaingan yang dilakukannya" Besar kecilnya ganti rugi ditetapkan oleh KPPU berdasarkan pada pembuktian kerugian senyatanya oleh pelaku usaha yang merasa dirugikan. Dalam ilmu hukum, pengertian ganti rugi dapat dibedakan ke dalam beberapa kategori, yaitu ${ }^{12}$ :

1) Ganti rugi nomimal, yaitu ganti rugi berupa pemberian sejumlah uang, meskipun kerugian sebenarnya tidak bisa dihitung dengan uang, bahkan bisa jadi tidak ada kerugian material sama sekali.

2) Ganti rugi penghukuman (punitive damages), yaitu suatu ganti rugi dalam jumlah besar yang melebihi dan jumlah kerugian yang sebenarnya, ganti rugi

${ }^{12}$ Susanti Adi Nugroho, Ibid, hlm. 566 
itu dimaksudkan sebagai hukuman bagi si pelaku.

3) Ganti rugi aktual (actual damages), yaitu kerugian yang benar-benar diderita secara aktual dan dapat dihitung dengan mudah sampai ke nilai rupiah.

4) Ganti rugi campur aduk (remedy meddling), yaitu suatu variasi dan berbagai taktik dimana pihak kreditur berusaha untuk memperbesar haknya jika pihak debitur wanprestasi dan mengurangi/menghapuskan kewajibannya jika digugat oleh pihak lain dalam kontrak tersebut.

Dengan melihat pengaturan sebagaimana isi Pasal 52 tersebut, ada beberapa interpretasi terhadap kewenangan dalam penanganan perkara persaingan usaha, baik sebelum maupun sesudah UU No. 5 Tahun 1999 diberlakukan. Ada dua pemahaman bahwa kewenangan penanganan perkara persaingan ada pada:

a) KPPU, yaitu untuk perkara persaingan usaha sebagaimana yang diatur oleh UU No. 5 Tahun 1999.

b) Pengadilan Negeri, untuk perkara persaingan curang (pelanggaran pidana) maupun melalui perbuatan melawan hukum (on. rechtmatigedaad) dengan menggunakan Pasal 1365 BW yang menimbulkan kerugian.

Perbedaan pendapat tersebut masih berlanjut sampai kini. Namun, dalam perkembangannya yang berbeda hanyalah kon-teksnya. Bukan lagi dari segi kewenangan, melainkan dan pertanyaan apakah KPPU sanggup menyelesaikan seluruh perkara persaingan usaha yang ada. Hal itu terlihat dari fakta bahwa sampai tahun 2008, KPPU telah menenima lebih dari 1000 laporan dan KPPU hanya dapat memproses laporan dan mengeluarkan putusan sekitar 120 putusan. KPPU dipertanyakan kemampuannya untuk menyelesaikan seluruh perkara persaingan yang laporannya telah diterima. Bila melihat kemampuan dalam kurun waktu 10 tahun terakhir, memang sudah saatnya untuk berpikir kembali mengenai kewenangan KPPU serta interaksi dengan lembaga lain; dalam hal ini adalah peran lembaga peradilan. Pertimbangan itu dilakukan untuk menyelesaikan perkara persaingan usaha yang semakin meningkat dan tingkatnya semakin kompleks.

Sementara itu, bila kewenangan tersebut diserahkan kepada pihak lain, yang paling mempunyai kewenangan sebagai lembaga pemutus adalah lembaga peradilan. Masalah lainnya adalah pertanyaan mengenai kemampuan dalam bidang ekonomi yang menjadi dasar dalam hukum persaingan usaha. Harus diakui bahwa mayoritas hakim di Indonesia kurang memiliki pengetahuan yang memadai dalam bidang ekonomi. Hakim yang mempunyai latar belakang ekonomi dan berada di peradilan niaga berjumlah sedikit dibandingkan dengan kebutuhan yang ada. Dengan latar belakang itu, tentunya hakim akan mengalami kesulitan dalam memeriksa kasus persaingan usaha yang kental dengan nuansa ekonomi, yang pada akhirnya akan memengaruhi proses penegakan hukum persaingan itu sendiri. Di sisi lain, anggota KPPU terdiri dari kumpulan ahli, baik di bidang ekonomi maupun hukum. Dengan demikian, keahlian mereka akan sangat berguna dalam proses peme-riksaan kasus persaingan usaha. Namun, penyerahan kompetensi absolut dalam menangani kasus persaingan usaha bukanlah tanpa adanya kontrol atau checks and balance dari lembaga peradilan. Sebelum KPPU benar-benar diberikan kewenangan absolut dalam kasus persaingan usaha, KPPU harus menunjukkan kepada dunia hukum Indonesia bahwa proses di KPPU telah sejalan dengan pninsip-pninsip hukum yang berlaku di Indonesia, termasuk di dalamnya hak untuk banding dan prasangka tidak bensalah (presumption of innocence) ${ }^{13}$.

Sehubungan dengan kewenangan, KPPU menetapkan nilai ganti rugi kepada 
pihak yang dirugikan, berikut adalah beberapa permasalahan hukum yang terkait ${ }^{14}$ :

1) Dalam beberapa putusan, KPPU memasukkan perhitungan kerugian konsumen dalam pertimbangan hukumnya, namun tidak memutuskan pemberian ganti rugi ke dalam amar putusannya. Dalam hal ini, dapat diartikan bahwa KPPU menilai pemberian ganti rugi tidaklah diperlukan ataupun KPPU menilai bahwa pemberian ganti rugi sudah tercakup dalam sanksi ad-ministratif yang ditetapkan.

2) Salah satu isu hukum terkait kewenangan KPPU menetapkan kerugian adalah mengenai rasio penghitungan denda yang dijatuhkan oleh KPPU terhadap pelaku usaha. UU No. 5 Tahun 1999 hanya memberikan ketentuan bahwa denda berkisar antara I miliar sampai dengan 25 miliar rupiah. Namun, dalam beberapa putusannya, KPPU tidak pernah menjelaskan dan mana denda yang ditetapkan tersebut dihitung. Hal ini bertentangan dengan prinsip dalam hukum acara perdata, di mana setiap jumlah yang didalilkan harus dibuktikan dasar penghitungannya, atau dengan kata lain pengenaan sanksi berupa denda harus ada dasarnya.

Permasalahan tersebut sudah dicoba untuk dijawab oleh KPPU dengan menerbitkan Keputusan KPPU No. 252/ KPPU/Kep/ VII/2008 tentang Pedoman Pelaksanaan Ketentuan Pasal 47 UU No. 5 Tahun 1999 (Pedoman Pasal 47). Berdasarkan Pedoman Pasal 47, mekanisme perhitungan denda sebagai berikut:

a) Penentuan besaran nilai dasar.

Besaran nilai dasar akan dihitung melalui perhitungan nilai penjualan dan penentuan nilai dasar denda. Nilai pen-jualan akan dihitung berdasarkan nilai keseluruhan penjualan pada tahun

${ }^{14}$ Susanti Adi Nugroho, Loc. Cit sebelum pelanggaran dilakukan. Adapun nilai denda akan terkait dengan proporsi nilai penjualan yang akan ber-gantung dan tingkat pelanggaran yang nantinya akan dikalikan dengan jumlah tahun pelanggaran.

b) Penyesuaian terhadap besaran nilai denda.

Dalam menentukan denda, KPPU akan mernpertimbangkan hal-hal yang dapat memberatkan atau meringankan besar-an nilai dasar denda.

c) Rentang besaran denda.

Jumlah akhir dan besaran denda dalam keadaan apa pun, tidak boleh melebihi Rp 25 miliar (dua puluh lima miliar rupiah).

d) Kemampuan untuk membayar.

KPPU berdasarkan permintaan pihak terlapor dapat mempertimbangkan kemampuan membayar dari terlapor pada konteks sosial dan ekonomi tertentu. Pengurangan akan diberikan secara individu berdasarkan pada bukti ob-jektif, yaitu bila denda tersebut akan berakibat pada bangkrutnya perusa-haan.

Berdasarkan pada mekanisme perhitungan denda di atas, KPPU memiliki dasar untuk menjatuhkan denda terhadap pelaku usaha termasuk dasar pengenaan besaran denda itu sendiri. Namun dalam perkem-bangannya, setelah adanya pedoman Pasal 47, ternyata KPPU tetap tidak memberikan perincian atas perhitungan denda.

Sebagai contoh adalah Perkara Carrefour tahun 2009. Di dalam Perkara Carrefour terkait dengan perhitungan pengenaan denda, KPPU memberikan pertim-bangan sebagai berikut: "Menimbang bahwa berdasarkan Pedoman Pasal 47 UU No. 5 Tahun 1999 tentang Tindakan Administratif, maka perhitungan denda didasarkan pada nilai penjualan terlapor pada pasar bersangkutan. Nilai trading terms terlapor setelah melakukan 
akuisisi Alfa pada tahun 2008 adalah sebesar Rp 1.422.042.000.098,00 (satu triliun empat ratus dua puluh dua miliar empat puluh dua juta sembilan puluh delapan rupiah), belum termasuk nilai trading terms yang diperoleh pada tahun 2009. Dengan menggunakan rumus dalam Pedoman Pasal 47 UU No. 5 Tahun 1999, perhitungan denda bagi terlapor adalah sebesar Rp 284.408.400.020,00 (dua ratus delapan puluh empat miliar empat ratus delapan juta empat ratus ribu dua puluh rupiah), sehingga melampaui batas maksimal denda yang ditetapkan dalam Pasal 47 hurufg UU No. 5 Tahun 1999".

Berdasarkan pertimbangan tersebut, KPPU memutuskan untuk mengenakan denda terhadap PT Carrefour Indonesia sebesar dua puluh lima miliar rupiah. Walaupun KPPU menyatakan menggunakan rumus dalam Pedoman Pasal 47, namun KPPU tetap tidak memberikan perincian yang menjelaskan dan mana angka dua puluh lima miliar rupiah tersebut didapat, dan hanya memberikan pertimbangan singkat mengenai nilai penjualan terlapor.

\section{a. Pengenaan denda serendah- rendahnya $R p$ 1.000.000.000,- (satu miliar rupiah) dan setinggi-tingginya Rp 25.000.000.000,- (dua puluh lima miliar rupiah)}

Dalam Pedoman Keputusan KPPU No. 252/KPPU/Kep/VII/2008 denda didefinisikan sebagai: "Denda merupakan usaha untuk mengambil keuntungan yang didapatkan oleh pelaku usaha yang dihasilkan dan tindakan anti-persaingan. Selain itu, denda juga ditujukan untuk menjerakan pelaku usaha agar tidak melakukan tindakan serupa atau ditiru oleh calon pelanggar lainnya. Agar efek jera dapat diterapkan efektif, secara ekonomi denda yang ditetapkan harus dapat menjadi sinyal atau setidaknya dipersepsikan oleh pelanggar sebagai biaya (expected cost) yang jauh lebih besar dibandingkan dengan manfaat (expected benefit) yang didapat dan tindakannya melanggar hukum persaingan usaha. Secara administrasi, pembayaran denda disetorkan oleh pelanggar kepada negara." KPPU dalam menentukan besaran denda akan menempuh dua langkah, yaitu:

1) Menentukan besaran nilai dasar.

2) Melakukan penyesuaian dengan menambahkan atau mengurangi besaran nilai dasar tersebut.

\section{Kendala-Kendala yang Timbul dalam Upaya Keberatan Terhadap Putusan KPPU}

\section{a. Mekanisme "Keberatan" Tidak Di- kenal dalam Hukum Acara}

Pasal 44 ayat (2) UU No. 5 Tahun 1999 menentukan bahwa pelaku usaha dapat mengajukan keberatan kepada pengadilan negeri sclambat-lambatnya 14 hari setelah menerima pemberitahuan putusan. Permasalahan mulai timbul jika ada permo-honan "keberatan" yang diajukan oleh pelaku usaha atas putusan KPPU. Tim-bulnya permasalahan dikarenakan "kebera-tan" bukanlah suatu upaya hukum yang di-kenal dalam hukum acara di Indonesia, dan UU No. 5 Tahun 1999 tidak memberikan suatu petunjuk teknis bagaimana prosedur pengajuan permohonan keberatan mi di-ajukan, dan bagaimana pengadilan negeri memproses permohonan keberatannya, karena belum ada acara yang secara jelas mengatur perihal proses keberatan terhadap kasuskasus persaingan usaha. Dalam hu-kum acara kita hanya mengenal tiga bentuk pengajuan yang dapat diajukan ke pengadilan negeri, yaitu gugatan, perlawanan, dan permohonan. Apakah upaya keberatan itu diposisikan sebagai upaya banding atas putusan KPPU atau sebagai pengajuan gugatan atau permohonan baru ke pengadilan negeri atas adanya putusan KPPU tersebut.

\section{b. Keterbatasan Waktu untuk Memeriksa Perkara Keberatan}

Satu-satunya upaya hukum yang tersedia yang dapat diajukan oleh pelaku usaha adalah mengajukan keberatan, 
sedangkan keberatan sendiri bukanlah suatu upaya hukum yang dikenal dalam hukum acara di Indonesia. Di samping tidak adanya petun-juk pelaksanaannya, dan bagaimana meka-nisme keberatan diajukan, UU No. 5 Tahun 1999 juga menetapkan secara eksplisit batasan waktu dalam proses pemeriksaan keberatan di pengadilan negeri, seperti yang ditentukan dalam Pasal 45 ayat (2) UU No. 5 Tahun 1999. Suatu perkara persaingan usaha yang masuk ke pengadilan negeri harus segera diputuskan dalarn jangka waktu 30 (tiga puluh) hari sejak perkara ter-sebut diterima oleh pengadilan negeri yang bersangkutan. Pemilihan waktu yang sing-kat tersebut pada awalnya lebih didasari agar pengadilan negeri dalam memeriksa perkara persaingan usaha dapat lebih efektif dan tidak berlarut-larut, sehingga dapat di-putuskan dalam waktu yang ditentukan.

\section{c. Keberatan Tidak dapat Diajukan ke Pengadilan Tata Usaha Negara}

Dan apakah pelaku usaha yang tidak setuju dengan putusan KPPU dapat mengajukan keberatan ke pengadilan tata usaha negara (TUN)? Hal ini menimbulkan permasalahan, karena semula putusan KPPU dianggap sebagai objek TUN, sehingga KPPU dapat menjadi subyek pada pengadilan TUN. Apakah hal ini mungkin, karena KPPU bukanlah institusi yang menjalankan urusan pemerintahan sebagaimana diatur dalam Pasal 1 angka 2 UU No. 5 Tahun 1986 sebagaimana telah diubah dengan UU No. 9 Tahun 2004 tentang Peru-bahan atas Undang-undang No. 5 Tahun 1986 tentang Peradilan Tata Usaha Negara.

Meskipun telah jelas bahwa keberatan pelaku usaha terhadap putusan KPPU hanya dapat diajukan kepada pengadilan negeri, tetapi karena tidak ada ketentuan yang mengatur kewenangan atau ketidak-wenangan lingkungan peradilan lain, selain pada pengadilan negeri, dalam mengatur masalah persaingan usaha, maka hal ini menimbulkan permasalahan tersen- diri. Keadaan ini menjadi rancu dan menim-bulkan ketidak pastian hukum dalam mena-ngani undangundang persaingan usaha. Namun dengan berjalannya waktu, dan setelah terbitnya Peraturan Mahkamah Agung (PERMA) No. 1 Tahun 2003, yang kemudian diperbarui melalui PERMA No. 3 Tahun 2005, tentang tata cara Pengajuan Upaya Hukum Keberatan Terhadap Putusan KPPU, permasalah tersebut telah diluruskan dalam Pasal 3 PERMA No. 3 Tahun 2005.

\section{d. Apakah Pelaku Usaha Pelapor dapat Juga Mengajukan Keberatan.}

Ketentuan Pasal 44 ayat (2) UU No. 5 Tahun 1999 menyatakan, "Pelaku usaha dapat mengajukan keberatan kepada penga-dilan negeri selambat-lambatnya 14 (empat belas) hari setelah menerirna pemberi-tahuan putusan." Ketentuan tersebut tidak memberi penjelasan apakah pelaku usaha pelapor atau pelaku usaha terlapor yang dapat mengajukan keberatan.

Hal tersebut sampai sekarang tetap menimbulkan permasalahan, karena dianggap tidak memberi keadilan yang sama antara Pelapor dan Terlapor, dan sampai di mana kewenangan PERMA dalam menafsirkan peraturan perundang-undangan yang tidak jelas. Terlepas dari permasalahan tersebut, Pasal 2 ayat (1) dan ayat (3) PERMA No. 3 Tahun 2005 telah menentukan bahwa, "Keberatan terhadap putusan KPPU hanya diajukan oleh pelaku usaha terlapor kepada pengadilan negeri ditempat kedudukan hukum usaha pelaku usaha tersebut." Dalam hal diajukan keberatan, KPPU merupakan pihak. Pandangan PERMA ini di karenakan pemeriksaan keberatan di pengadilan negeri diposisikan sebagai upaya hukum banding terhadap putusan KPPU, sehingga pihak yang dapat mengajukan banding adalah hanya pihak yang tertera dalam berkas perkara. 


\section{e. Tidak Ada Kejelasan di Pengadilan Negeri Mana Keberatan Diajukan}

Ketentuan Pasal 44 ayat (2) UU No. 5 Tahun 1999,menyatakan bahwa pelaku usaha dapat mengajukan keberatan kepada Pengadilan negeri selambatlambatnya 14 (empat belas) hari setelah menerima pem-beritahuan putusan tersebut. Ketentuan tersebut tidak memberi penjelasan di penga-dilan negeri mana keberatan diajukan, selain menyatakan “cukup jelas' Seperti dikemukakan di atas, permasalahan tersebut telah diluruskan dalam Pasal 2 ayat (1) PERMA bahwa, "Keberatan terhadap putu-san KPPU hanya diajukan oleh pelaku usaha terlapor kepada pengadilan negeri ditempat kedudukan hukum usaha pelaku usaha tersebut. Keberatan diajukan melalui kepaniteraan pengadilan negeni yang ber-sangkutan sesuai dengan prosedur pendaf-taran perkara perdata dengan memberikan salman keberatan kepada KPPU. Namun hal ini juga masih menimbulkan permasalahan jika pelaku usaha atau badan hukum terlapor lebih dan satu, sehingga masing masin akan mengajukan keberatannya di pengadilan negeri tempat kedudukan hukumnya. Dan, hal ini akan menimbulkan kebingungan dan tidak ada kepastian hukum, jika masing-masing pengadilan negeri memberikan putusan yang berbedabeda, padahal berasal dan putusan KPPU yang sama.

\section{f. Kewenangan Pengadilan Negeri Dalam Memeriksa Perkara Keberatan Atas Putusan KPPU}

Keberatan merupakan satu-satunya upaya hukum terhadap putusan KPPU yang dapat diajukan oleh pelaku usaha, dalam hal ini untuk terlapor. Pasal 44 ayat (2) sebagai dasar hukum pengajuan keberatan me-nyebutkan bahwa pelaku usaha dapat mengajukan keberatan kepada pengadilan negeri selambat-lambatnya 14 (empat belas) hari setelah menerima pembenitahuan putusan tersebut. Pengadilan negeni ditetapkan UU memeriksa perkara keberatan dalam waktu 14 (empat belas) hari sejak diterimanya keberatan dan harus memberikan putusan dalam waktu 30 (tiga puluh) hari sejak dimulainya pemeniksaan keberatan. UU tidak memberi penjelasan sampai di mana kewenangan pengadilan negeri untuk memeriksa dan menilai putusan KPPU? Apakah pemeriksaan yang dilakukan oleh hakim pengadilan negeni hanya aspek formal, atau juga termasuk boleh menilai pokok perkara dan hal-hal lain yang menyangkut aspek matenialnya? ini juga dapat menimbulkan penmasalahan jika hakim dapat memeriksa keseluruhan substansi keberatan yang diajukan, baik aspek formal maupun aspek materialnya, ini akan berisiko putusan yang berbeda, karena adanya perbedaan pandangan.

Beranjak dari apa yang telah dikemukakan di atas, maka dalam rangka penegakan UU No. 5 Tahun 1999 sebagai upaya menciptakan iklim persaingan usaha yang sehat dan kompetitif diperlukan adanya kesepahaman visi, misi, dan orientasi antara KPPU dengan pengadilan negeri. Tanpa terciptanya hubungan yang koordinatif antara kedua lembaga itu, maka penegakan UU No. 5 Tahun 1999 tidak akan berjalan efektif sebagaimana yang diharapkan.

Upaya hukum keberatan terhadap putusan KPPU hanya dapat diajukan oleh pelaku usaha terlapor kepada pengadilan negeri ditempat kedudukan hukum pelaku usaha tersebut. PERMA juga menetapkan bahwa KPPU menjadi pihak dalam proses keberatan ini, dengan tujuan agar KPPU dapat memberi penjelasan/verifikasi dalam proses pemeriksaan keberatan dan memper-tahankan putusannya. Dengan demikian, maka pelaku usaha pelapor tertutup untuk mengajukan keberatan manakala penga-duannya tidak ditindaklanjuti oleh KPPU. Ketentuan tersebut wajar, kanena pelaku usaha pelapor juga bukan menjadi pihak dalam putusan KPPU.

Pemeriksaan tambahan dilakukan oleh majelis komisi yang memutus putusan komisi yang diajukan keberatan. Hasil pe- 
meriksaan tambahan dicatat dalam berita acara pemeriksaan tambahan yang ditandatangani oleh pihak yang diperiksa majelis hakim, dan panitera. Hasil pemeriksaan tambahan oleh sekretariat komisi disam-paikan kepada majelis hakim yang mena-ngani perkara keberatan.

Jika masih ada pelaku usaha yang tidak setuju atas putusan keberatan yang dijatuhkan oleh pengadilan negeri, maka UU No. 5 tahun 1999 memberikan upaya hukum yang dapat ditempuh oleh pihak yang masih berkeberatan, baik pihak terlapor maupun KPPU, untuk mengajukan kasasi ke Mahkamah Agung, dalam kurun waktu 14 hari sejak putusan keberatan diberitahukan oleh pengadilan negeri. Dan, Mahkamah Agung harus memberikan putusan kasasi dalarn kurun waktu 30 hari sejak permohonan kasasi diterima. Hukum acara yang dipakai untuk pemeriksaan ini adalah hukum acara perdata biasa.

\section{Implementasi Penegakan Hukum Persaingan Usaha}

\section{a. Mengenai Proses Keberatan di Pengadilan Negeri}

Ketiadaan regulasi yang secara jelas mengatur upaya hukum Keberatan baik di dalam UU No.5/1999 maupun di dalam hukum acara formal menyebabkan proses pemeriksaan upaya hukum Keberatan di Pengadilan Negeri menjadi rancu, akibat-nya pelaku usaha serta terutama Pengadilan Negeri menjadi bingung dalam menerapkan proses yang tepat dalam pengajuan kebe-ratan. Pada akhirnya Pengadilan Negeri menerima seluruh keberatan tersebut dan kemudian memperlakukan proses keberatan sebagaimana layaknya kasus perdata umum yang masuk ke Pengadilan Negeri ${ }^{15}$. Dalam hal ini Pengadilan Negeri memperlakukan keberatan sebagai bentuk permohonan atau gugatan biasa, yang tentunya sangat ber-beda apabila dibandingkan dengan proses keberatan

${ }^{15}$ Susanti Nugroho, Op. Cit., hlm. 554 yang telah dideskripsikan secara sangat singkat di dalam undang-undang.

\section{b. Kontroversi Seputar Kewenangan dalam Penanganan Perkara Per- saingan Usaha}

Selain itu disamping permasalahan yang terkait dengan proses pemeriksaan perkara persaingan usaha di Pengadilan, hal lain yang juga menjadi pertanyaan bagi banyak pihakadalah mengenai kewenangan relatif peradilan yang berhak memeriksa perkarsaingan usaha apabila pihak yang mengajukan keberatan lebih dati satu. Isu ini berkembang mengingat dalarn kasus Indomobil terdapat lebih dan satu pihak yang mengajukan keberatan kepada Pengadilan Negeri yang berbeda-beda. Kondisi ini dapat menyebabkan kemungkinan timbulnya putusan yang berbeda-beda dan berbagai Pengadilan Negeri tersebut (walaupun dalam kasus Indomobil seluruh keberatan diterima oleh Pengadilan Negeri dengan keputusan yang relatif sama yaitu membatalkan putusan KPPU).

Disamping kewenangan relatif, kompetensi absolut KPPU sebagai lembaga yang ditunjuk oleh undang-undang untuk mengawasi praktek persaingan usaha di Indonesia juga dipertanyakan oleh banyak pihak. Kedudukan KPPU sebagai lembaga independen khusus yang tidak diatur secara jelas di dalam sistem hukum Indonesia menyebabkan banyak pihak yang menentang diberikannya kewenangan yang sangat luas kepada KPPU.

Putusan KPPU yang diajukan ke Pengadilan TUN adalah suatu fenomena menarik karena menurut pendapat ahli, KPPU bukanlah subjek yang dapat diajukan kepada Pengadilan TUN, hal ini mengingat putusan yang dikeluarkan oleh KPPU bukanlah keputusan yang dikeluarkan oleh Pejabat Tata Usaha Negara dan masih dapat ditnintakan proses keberatan ke Pengadilan Negeri serta kasasi ke Mahkamah Agung.

\section{a. Putusan KPPU}

\section{Sifat dan Bentuk Putusan KPPU}


Dalam penjelasan Pasal 43 Ayat (3) tersebut disebutkan, bahwa pengambilan keputusan KPPU sebagaimana dimaksud ayat (3) dilakukan dalam suatu Sidang Majelis yang beranggotakan sekurangkurangnya 3 (tiga) orang Anggota Komisi. Hal ini juga telah diperjelaskan didalam Pasal 7 ayat (1), (2) dan (3) Keputusan Presiden Nomor 75 Tahun 1999.

Atas dasar Putusan KPPU yang menyatakan terbukti adanya pelanggaran terhadap ketentuan UU No.5 Tahun 1999, maka KPPU sesuai dengan kewenangannya dapat menjatuhkan sanksi administrasi dalam putusannya. UU No. 5 Tahun 1999 juga memberikan kesempatan bagi Pihak Terlapor untuk menggunakan upaya hukum keberatan, namun jika Pihak Terlapor menerima putusan tersebut dengan tidak melakukan upaya hukum keberatan, maka keputusan KPPU tersebut berkekuatan hukum tetap atau inkraht van geweijde.

\section{Eksekusi Putusan KPPU}

Ada dua golongan putusan, yaitu putusan sela dan putusan akhir. salah satu putusan sela yang dikenal dalam H.I.R. ialah yang disebut putusan provisionil. Selain itu juga ada putusan semata-mata. misalnya, intervensi dan adanya pemanggilan pihak ketiga sebagai penjamin.

Sedang menurut sifatnya dikenal tiga macam putusan yaitu:

a. Putusan declaratoir

b. Putusan consititu tif.

c. Putusan condemnatoir.

ad. (a) Putusan declaratoir adalah putusan yang bersifat hanya menerangkan, menegaskan suatu keadaan hukum sematamata. Misalanya, bahwa A adalah anak angkat yang sah dari $\mathrm{X}$ dan $\mathrm{Y}$, atau bahwa $\mathrm{A}, \mathrm{B}$ dan $\mathrm{C}$ adalah ahliwaris dari almarhum $\mathrm{Z}$.

ad. (b) Putusan constitutif adalah putusan yang meniadakan suatu keadaan hukum atau minimbulkan suatu keadaan hukum yang baru, contohnya, adalah putusan perceraian, putusan yang menyatakan seorang jatuh pailit.

ad. (c) Putusan condemnatoir adalah putusan yang berisakan penghukuman. Misalnya, di mana pihak tergugat dihukum untuk meyerahkan sebidang tanah berikut bangunan rumahnya membayar utang.

Pada umumnya dalam suatu putusan Hakim memuat beberap macam putusan, atau dengan lain perkataan merupakan penggabungan dari putusan declaratoir dan putusan constitutif atau penggabungan antara putusan declaratoir dengan putusan condemnatoir dan sebagainya.

\section{KESIMPULAN}

Kedudukan atau status dari KPPU dalam menjalankan fungsi kewenangannya menjadi hal yang sangat penting, mengingat UU No. 5 Tahun 1999 telah memberikan KPPU kewenangan yang sangat besar, se-hingga menyerupai kewenangan lembaga peradilan (quasai judicial). Pasal 35 dan Pasal 36 UndangUndang No. 5 Tahun 1999 secara tegas memberikan kewenangan yang sangat luas kepada KPPU untuk dapat berlaku sebagai penyidik, penuntut maupun sebagai pemutus terhadap kasus-kasus per-saingan usaha. dalam konteks demikian maka timbul opini yang menganggap bahwa KPPU adalah sebagai peradilan khusus untuk kasus persaingan usaha.

Dipandang dari sifat putusan KPPU yang otomatis memiliki kekuatan hukum tetap apabila terhadapnya tidak diajukan keberatan dan penegakan melalui mekanisme penetapan untuk eksekusi ke pengadilan negeri, maka proses hukum yang seharusnya melanjuti proses penegakan putusan KPPU adalah upaya hukum eksekusi, yang didasarkan kepada penetapan eksekusi pengadilan negeri. Putusan KPPU tidak bisa eksekusi oleh KPPU sendiri, karena dalam kepala putusan tidak mencantumkan irah-irah "Demi Keadilan Berdasarkan Ketuhan yang Maha Esa". 


\section{DAFTAR PUSAKA}

Richard A Posner, Anti Trust Law (an Economic Persfetive) dalam A. M. Tri Anggraeni, Larangan Praktek Monopoli dan Persaingan Usaha Tidak Sehat Perse Ilegal atau Rule of Regoin, Fak. Hukum Universitas Indonesia, Jakarta, 2003.
Susanti Adi Nurgroho, Hukum Persaingan Usaha di Indonesia Dalam Teori dan Praktik Serta Penerapan Hukumnya, Kencana, Jakarta, 2014.

Ralph H. Folsoni dan Michael W. Gordon, Internasional Business Transactions, (St. Paul: Westt Publishing Co.1995) 